\title{
Microfouling communities from pelagic and benthic marine plastic debris sampled across Mediterranean coastal waters
}

\author{
Mercedes Masó $^{1}$, José-Manuel Fortuño ${ }^{2}$, Silvia de Juan ${ }^{3}$, Montserrat Demestre ${ }^{2}$ \\ ${ }^{1}$ Institut de Ciències del Mar, CSIC (leave of absence), Mas Ginesta, 5. 17253 Vall-Llobrega, Girona, Spain. \\ ${ }^{2}$ Institut de Ciències del Mar, CSIC, Psg. Marítim de la Barceloneta 37-49, 08003 Barcelona, Spain. \\ E-mail: montse@icm.csic.es \\ ${ }^{3}$ Centro de Conservación Marina, Departamento de Ecología, Facultad de Ciencias Biológicas, Pontificia Universidad \\ Católica de Chile, Casilla 114-D, Santiago, Chile.
}

\begin{abstract}
Summary: The present study used scanning electron microscopy to characterize the organisms colonizing marine plastic debris collected from pelagic and benthic habitats across Mediterranean coastal waters of Greece, Italy and Spain. A total of 42 fragments of plastic were collected during the COMSOM experimental cruise, 16 from the seafloor and 26 from surface waters. The results showed that diatoms were the most abundant organisms on both pelagic and benthic plastics. The diatom Ceratoneis closterium, frequently observed on surface plastics (73\%), is a harmful microalgae associated with mucilage events in the Mediterranean. The abundance of marine plastic in coastal and oceanic waters may provide new habitats that offer an easy substrate for these invasive organisms. Furthermore, the colonization of these new environments might reduce the success of life strategies, or drive the organisms out of their essential habitat by dispersion and rafting phenomena. The results of the present work highlight the need to increase our knowledge of the consequences of colonization of plastics introduced into the marine environment, and the need to raise awareness of the potential impacts of debris accumulation on biodiversity of marine ecosystems.
\end{abstract}

Keywords: scanning electron microscope; marine plastic debris; biofouling; northern Mediterranean Sea.

Comunidades de microfouling de los plásticos pelágicos y bentónicos muestreados en aguas costeras mediterráneas

Resumen: El presente estudio utilizó el microscopio electrónico de barrido para caracterizar los organismos colonizadores de los plásticos de hábitats pelágicos y bentónicos de las aguas costeras mediterráneas de Grecia, Italia y España. Durante la campaña COMSOM se muestrearon un total de 42 fragmentos de plásticos, 16 de fondo y 26 de superficie. Los resultados evidenciaron que las diatomeas fueron los organismos más abundantes tanto en los plásticos pelágicos como en los bentónicos. Cabe mencionar que la diatomea Ceratoneis closterium, observada frecuentemente en plásticos de superficie (73\%), es una especie de alga nociva asociada a fenómenos de mucílago en el Mediterráneo. La abundancia de los plásticos marinos en aguas costeras y oceánicas puede proporcionar nuevos hábitats que ofrecen un substrato fácil para los organismos invasores. Además, la colonización de estos nuevos ambientes puede reducir el éxito de las estrategias de vida, o alejar a los organismos de sus hábitats esenciales mediante fenómenos de dispersión o de transporte mediante "rafting". Los resultados de este trabajo ponen de relieve la necesidad de aumentar nuestro conocimiento sobre las consecuencias de la colonización de los plásticos introducidos en el medio marino y, al mismo tiempo, la necesidad de concienciar sobre sus impactos potenciales en la biodiversidad de los ecosistemas marinos.

Palabras clave: microscopio electrónico de barrido; basura de plásticos marinos; biofouling; norte del mar Mediterráneo.

Citation/Como citar este artículo: Masó M., Fortuño J.M., de Juan S., Demestre M. 2016. Microfouling communities from pelagic and benthic marine plastic debris sampled across Mediterranean coastal waters. Sci. Mar. 80S1: 117-127. doi: http:// dx.doi.org/10.3989/scimar.04281.10A

Editor: D. Vaqué.

Received: June 5, 2015. Accepted: October 14, 2015. Published: September 30, 2016.

Copyright: () 2016 CSIC. This is an open-access article distributed under the terms of the Creative Commons Attribution (CC-by) Spain 3.0 License. 


\section{INTRODUCTION}

Currently, it is broadly accepted that plastic pollution impacts the whole marine food web, from zooplankton to marine mammals (Andrady 2011, Cole et al. 2013). Ingestion, entanglement and suffocation of marine wildlife are the best-known problems caused by this type of pollution and are affecting marine habitats worldwide (see reviews by Derraik 2002, Gregory 2009, Cole et al. 2011). Most plastics are resistant to biodegradation, but will break down gradually due to exposure to UV radiation and heat, followed by mechanical action (Billingham et al. 2002, Andrady 2011), simulating components of the plankton community. This gradual fragmentation of plastics causes the release of toxins of the family biophenols or polychlorinated biphenyls (PCBs), which are incorporated into the marine food web (Barnes et al. 2009). PCBs and dichlorodiphenyldichloroethylene (DDE) are also adsorbed to polypropylene (PP) resin pellets from seawater. Plastic pellets act as pollutant accumulators that can transfer hydrophobic pollutants to organisms (Mato et al. 2001, Andrady 2011). A recent study estimates that more than five trillion plastic pieces are floating in the oceans (Eriksen et al. 2014) and this is only the visible face. It is believed that the majority of plastics (70\%) end up on the seabed (Hammer et al. 2012).

Marine biofouling is described as the undesired growth of marine organisms on submerged surfaces of anthropogenic origin (Callow and Callow 2002). Surfaces introduced into the marine environment are promptly covered by extracellular polymeric substances (EPS) produced by archaea, bacteria and eukaryotic microbes (Flemming et al. 2007). Polysaccharides, proteins, glycoproteins, glycolipids and other EPS substances create a matrix and retain particulate substances from the environment, providing nutrients for biofilm organisms (Flemming 2009). Micro- and macro-organisms such as diatoms, dinoflagellates, rotifers, arthropods, bivalves, gastropods, worms, tunicates, hydroids, sponges and macroalgae constitute a part of the fouling community. The development of this fouling community on tubes, maritime structures or boats has been causing problems for centuries. Due to the known adverse effects, the species, the biofouling process and also its potential solution have been largely investigated (Callow and Callow 2002, Schultz 2007, Callow and Callow 2011). However, biofouling on marine plastic debris (MPD) has only recently received attention, and current studies (Fortuño et al. 2010, Bravo et al. 2011, Goldstein et al. 2014) highlight the need for more research on the composition of biofouling communities, the structure of MPD and its impact on the marine environment.

To date, two main impacts have been associated with biofouling on MPD: species introduction and community changes. Benthic MPD provides a new colonization substrate for organisms, so MPD has the potential to change the structure of benthic communities and benthic biodiversity in general (Katsanevakis et al. 2007, Sánchez et al. 2013). Floating MPD also provides new habitats, but especially it offers a long-lasting material that can substantially raise the dispersion capacity of organisms (Aliani and Moldcard 2003, Thiel and Gutow 2005, Barnes et al. 2009). The potential large-scale dispersal of MPD, carrying a community of colonizing organisms, provides a vector for the transport of alien species (Barnes 2002, Thiel et al. 2003, Goldstein et al. 2014). Additionally, floating MPD has been suggested as a potential transport vector of harmful algae bloom (HAB) species (Masó et al. 2003).

Recently, the study of the microfouling community has gained attention due to its possible consequences for plastic degradation. The analysis of the microfouling community could provide clues for understanding the sources and fate of MPD. When plastics reach the sea, they are exposed to ultraviolet (UV) radiation and physical weathering leading to their fragmentation into small pieces: what is known as microplastics (Cole et al. 2011). Microfouling can act as a protection against UV radiation, which retards plastic fragmentation (O'Brine and Thompson 2010). On the other hand, microbes can play a role in increasing plastic degradation (Webb et al. 2009, Harshvardhan and Jha 2013).

Among the various processes that affect MPD when it reaches the marine environment, the most influential mechanism is biofouling causing density changes. Density increases with the biofilm development and the subsequent attachment of fouling organisms (Morét-Ferguson et al. 2010). Very little information is available on the causes and consequences of biofilm development. One of the best tools for studying microorganisms in the fouling community is scanning electron microscopy (SEM) (Delgado and Fortuño 1991, Cros and Fortuño 2002).

Three recent papers address for the first time the characterization by SEM of the microfouling community on floating microplastics collected in three different areas: the North Atlantic (Zettler et al. 2013), water around Australia (Reisser et al. 2014) and the North Pacific Gyre (Carson et al. 2013).

The objective of the present work is to further SEM studies by analysing both floating and benthic MPD and to contribute new scientific information on biofouling microorganisms. Detailed analysis of these organisms could provide new insights into the process of colonization and show whether this process continues when pelagic plastics sink to bottom, due to biofouling or due to the weight of the polymer itself, and new organisms are encrusted on the plastic substrate. The colonization of plastics probably also contributes to the modification of benthic ecosystem functioning. Therefore, the potential role of MPD as a new substrate to be colonized by marine organisms has gained importance in view of future effects on biodiversity changes and is also addressed in this study.

The study focuses on four coastal areas in the Mediterranean Sea (Fig. 1), where plastics were sampled during the COMSOM experimental cruise (Sánchez et al. 2013). Results from the previous work by Sánchez et al. (2013) showed high densities of plastics in each area surveyed (i.e. $60 \mathrm{pd} / \mathrm{ha}$ on the Catalan coast, northwestern Mediterranean, $59.5 \mathrm{pd} / \mathrm{ha}$ on the Central 


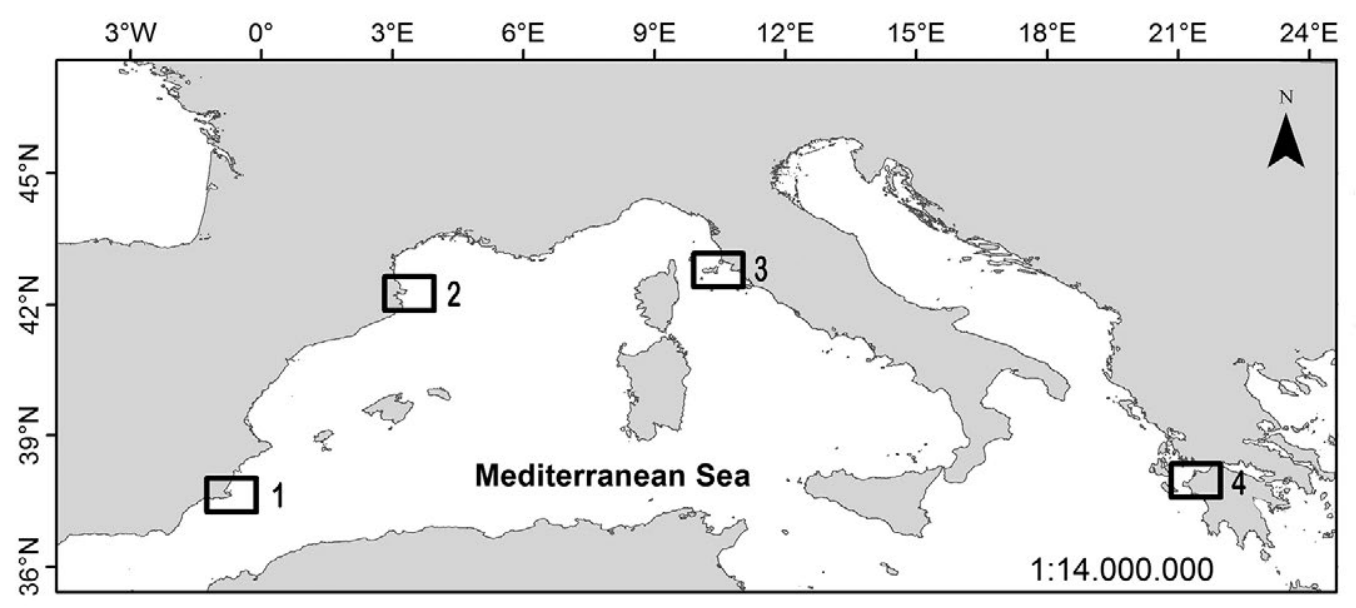

Fig. 1. - Map of the study area in the NW Mediterranean: 1, Murcia coast; 2, Catalan coast; 3, Tyrrhenian coast; 4, eastern Ionian coast.

Tyrrhenian coast, $34 \mathrm{pd} / \mathrm{ha}$ on the Murcia coast, southern Spanish Mediterranean, and $23 \mathrm{pd} / \mathrm{ha}$ on the eastern Ionian coast), representing higher values than those recorded in other areas of the Mediterranean, such as the Adriatic Sea, the Gulf of Lions and eastern Corsica (Galgani et al. 2000). The aim of the present paper is to characterize the microfouling communities of MPD by SEM observations from different marine habitats and to compare for the first time both pelagic and benthic biofouling organisms. The study focuses on the colonization of marine plastics in order to understand their significance as a source of impact on marine ecosystems and their wider environmental implications.

\section{MATERIALS AND METHODS}

The study is focuses on four coastal areas of the northern Mediterranean, located between 40 and $90 \mathrm{~m}$ depth: one in Italy, on the Central Tyrrhenian coast, one in Greece, on the eastern Ionian coast, and two in Spain, on the Murcia and Catalan coasts (Fig. 1) (see further details of the study areas in Demestre et al. 2010, de Juan and Demestre 2012). Samples of surface and benthic macroplastic debris were collected during an oceanographic cruise undertaken from the 21 May to the 24 June 2009.

Samples of macroplastics accumulated over the seabed (hereafter benthic plastics) were collected with an experimental dredge similar to a 2-m beam-trawl, with a $2 \times 40-\mathrm{cm}$ iron-framed aperture and a $10-\mathrm{mm}$ cod-end. To ensure continuous contact of the gear with the seabed, a Scanmar sensor was placed on the iron frame of the dredge. In each study area, 18 dredge samples were randomly collected performing a 15-minute tow at 2.5 $\mathrm{kn}$ following the sampling strategy used in epibenthic studies (de Juan et al. 2011). In a previous analysis conducted on these samples, Sánchez et al. (2013) showed that only $8 \%$ of collected plastics showed no sign of colonization, while the rest were covered by fouling organisms. A subset of 16 benthic plastics, in the first phase of succession of colonization, was selected to be analysed.

Samples of floating macroplastics (hereafter pelagic) were collected to characterize surface fouling organisms and compare this community with the community of organisms identified on benthic plastics. Surface sampling was performed using an inflatable boat and a hand-net with a $0.5 \times 0.5-\mathrm{m}$ iron-frame aperture and a $1-\mathrm{cm}$ mesh size to collect macroplastics. Sampling followed parallel transects of $20 \mathrm{~m}$ length. Each transect was covered for 15 minutes and the overall sampling area overlapped with the area where the benthic samples were collected. A total of 26 pelagic plastics were selected to be studied under the SEM.

For SEM studies, a subsample of the selected benthic and pelagic macroplastics was taken. The dimensions of the plastics were between 225 and $625 \mathrm{~mm}^{2}$. Samples were preserved either in $5 \%$ buffered formalin or in $2.5 \%$ glutaraldehyde buffered in filtered seawater. Samples were dehydrated with increasing concentrations of ethanol, critical-point-dried with $\mathrm{CO}_{2}$, mounted on aluminium stubs and sputter-coated with goldpalladium. The samples were observed with a Hitachi S-3500N scanning electron microscope operated at 5 $\mathrm{kV}$ at the Electron Microscopy Service of the Institute of Marine Sciences (CSIC), in Barcelona (Spain).

\section{RESULTS}

The analysis of pelagic and benthic plastics using a scanning electron microscope evidenced that the frequencies of eight large groups of colonizers qualitatively differentiated surface and seabed MPD microfouling communities (Table 1). Diatoms (Fig. 2) appeared in almost $100 \%$ of both benthic and pelagic MPD sampled. Dinoflagellates (Fig. 3 ) occurred in more than $50 \%$ of the pelagic MPD sampled, but rarely (13\%) on benthic MPD. Cocco-

Table 1. - Frequency of occurrence $(\%)$ of the most abundant taxonomic group on pelagic and benthic marine plastic debris (MPD).

\begin{tabular}{lcc}
\hline Group & Pelagic MPD $\mathrm{n}=26$ & Benthic MPD $\mathrm{n}=16$ \\
\hline Diatoms & 100 & 94 \\
Fungi & 85 & 13 \\
Dinoflagellates & 58 & 13 \\
Coccolithophores & 35 & 50 \\
Protozoa & 27 & 56 \\
Faecal pellet & 23 & 13 \\
Bryozoa & 4 & 44 \\
\hline
\end{tabular}



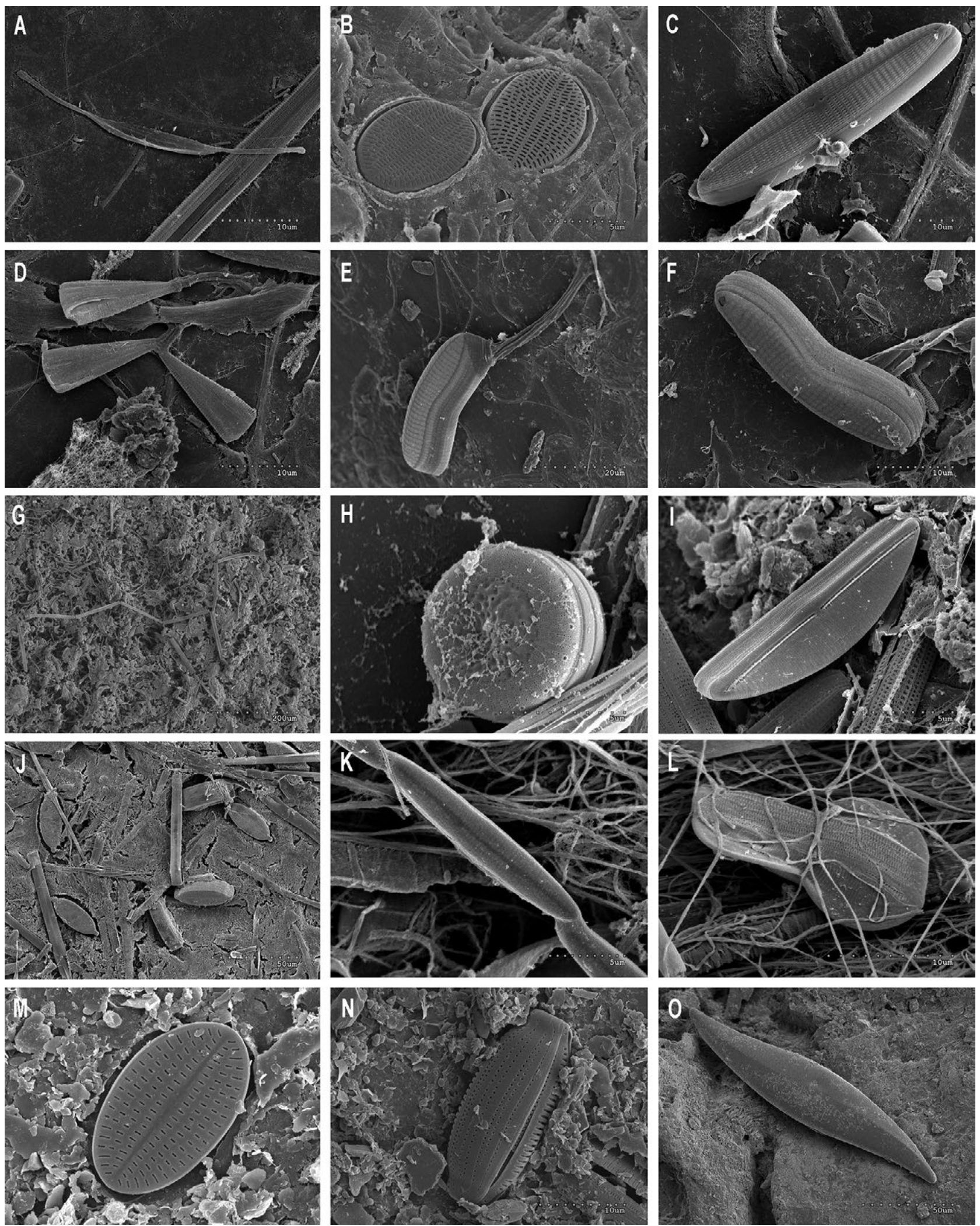

Fig. 2. - Diatoms. A-L, diatoms on pelagic plastics; M-O, diatoms on benthic plastics. A, Ceratoneis closterium; B, Cocconeis sp.; C, Navicula sp.; D, Licmophora sp.; E, F, Achnanthes sp.; G, Thalassionema nitzschioides; H, Cyclotella sp.; I, Cymbela sp.; J, diatoms like Mastogloia; K, chain of unidentified pinnate diatoms; L, Entomoneis; M, Cocconeis sp.; N, Amphora sp.; O, Pleurosigma sp.

lithophores (Fig. 4) were attached on both benthic and pelagic MPD, occurring with a relatively high frequency (Table 1). Fungi were the second group in frequency of appearance (Fig. 5L) on pelagic MPD, but this group only appeared sporadically on benthic MPD. Faecal pellets were detected in both domains although they were more frequently recorded on pelagic MPD. 

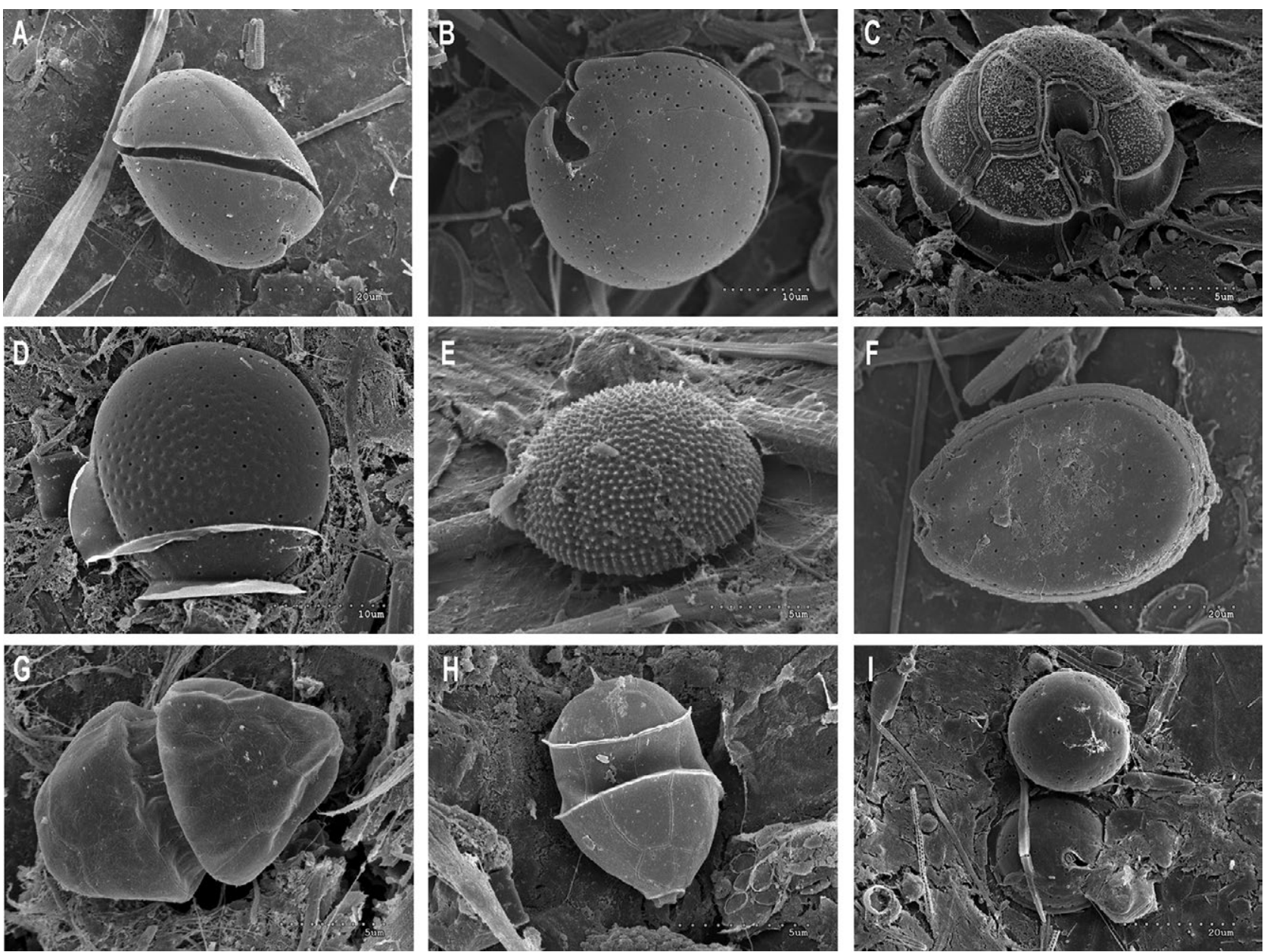

Fig. 3. - Dinoflagellates on pelagic plastics. A, B, Coolia sp.; C, Pentapharsodinium tirrenicum; D, Dinophysis sp.; E, Prorocentrum minimum; F, Prorocentrum lima; G, H, Heterocapsa sp.; I, Unidentified dinoflagellate.

Benthic and pelagic MPD had a very distinct appearance. Pelagic MPD was characterized, in most cases, by a well-developed biofilm containing a high amount of bacteria, fungi and diatoms (Fig. 5M). Bacteria were present in all analysed samples from both pelagic (Fig. $5 \mathrm{~A}, \mathrm{~B}, \mathrm{C})$ and benthic MPD. However, benthic MPD was covered by sediment, basically clay (Fig. 6A, C), which complicated identification of organisms. Benthic MPD was characterized by high quantities of sessile and pedunculated protozoans (Fig. 6A, B, C, D), as well as bryozoan colonies (Fig. 6H) (Table 1). Polychaetes (Fig. $6 \mathrm{G})$ were also identified with a moderate frequency and different species of hydrozoans were detected sporadically in both pelagic (Fig. 5D, E, F) and benthic MPD (Fig. 6E). Foraminifera were also identified in several communities (Fig. 6I) from benthic MPD.

The diatoms Ceratoneis, Cocconeis, Navicula, Thalassionema, Achnanthes, Amphora and Licmopho$\mathrm{ra}$ were the genera that characterized the microfouling community of MPD (Table 2, Fig. 2). The most conspicuous difference between the diatom fouling community from pelagic and from benthic plastics was the high occurrence of the pennate diatom Ceratoneis closterium in pelagic samples (73\%). The second genera in frequency of appearance on pelagic MPD, Cocconeis were the most frequently detected genera on benthic MPD. Achnanthes and Licmophora, both pedunculate
Table 2. - Frequency of occurrence (\%) of diatom genera identified on pelagic and benthic marine plastic debris (MPD). Third column, genera identified previously attached to plastic debris; a, Reisser et al. 2014; b; Zettler et al. 2013; c, Carpenter and Smith 1972.

\begin{tabular}{lccc}
\hline Diatom genera & $\begin{array}{c}\text { Pelagic MPD } \\
\mathrm{n}=26\end{array}$ & $\begin{array}{c}\text { Benthic MPD } \\
\mathrm{n}=16\end{array}$ & $\begin{array}{c}\text { Previously } \\
\text { documented }\end{array}$ \\
\hline Ceratoneis & $73 \%$ & $6 \%$ & \\
Cocconeis & $54 \%$ & $38 \%$ & $\mathrm{a}$ \\
Navicula & $50 \%$ & $13 \%$ & $\mathrm{~b}$ \\
Thalassionema & $42 \%$ & $0 \%$ & $\mathrm{a}$ \\
Achnanthes & $23 \%$ & $6 \%$ & $\mathrm{a}$ \\
Amphora & $23 \%$ & $19 \%$ & $\mathrm{a}$ \\
Licmophora & $19 \%$ & $0 \%$ & $\mathrm{a}$ \\
Fragilariopsis & $15 \%$ & $6 \%$ & $\mathrm{a}$ \\
Thalassiosira & $8 \%$ & $0 \%$ & $\mathrm{a}, \mathrm{c}$ \\
Mastogloia & $8 \%$ & $0 \%$ & $\mathrm{c}$ \\
Cyclotella & $4 \%$ & $0 \%$ & \\
Striatella & $4 \%$ & $0 \%$ & \\
Thalassiothrix & $4 \%$ & $0 \%$ & \\
Diploneis & $0 \%$ & $6 \%$ & \\
Cyst & $8 \%$ & $0 \%$ & \\
n.i & $62 \%$ & $81 \%$ & \\
\hline
\end{tabular}

diatoms, were present on $c a .20 \%$ of pelagic MPD but they were not detected on benthic MPD. However, a high number of diatoms could not be identified due to their poor state of preservation or because we could not observe their frustule details. The centric genus Cyclotella sp. was detected only in very few cases (Fig. 2H) and Pleurosigma sp. and Entomoneis sp were 

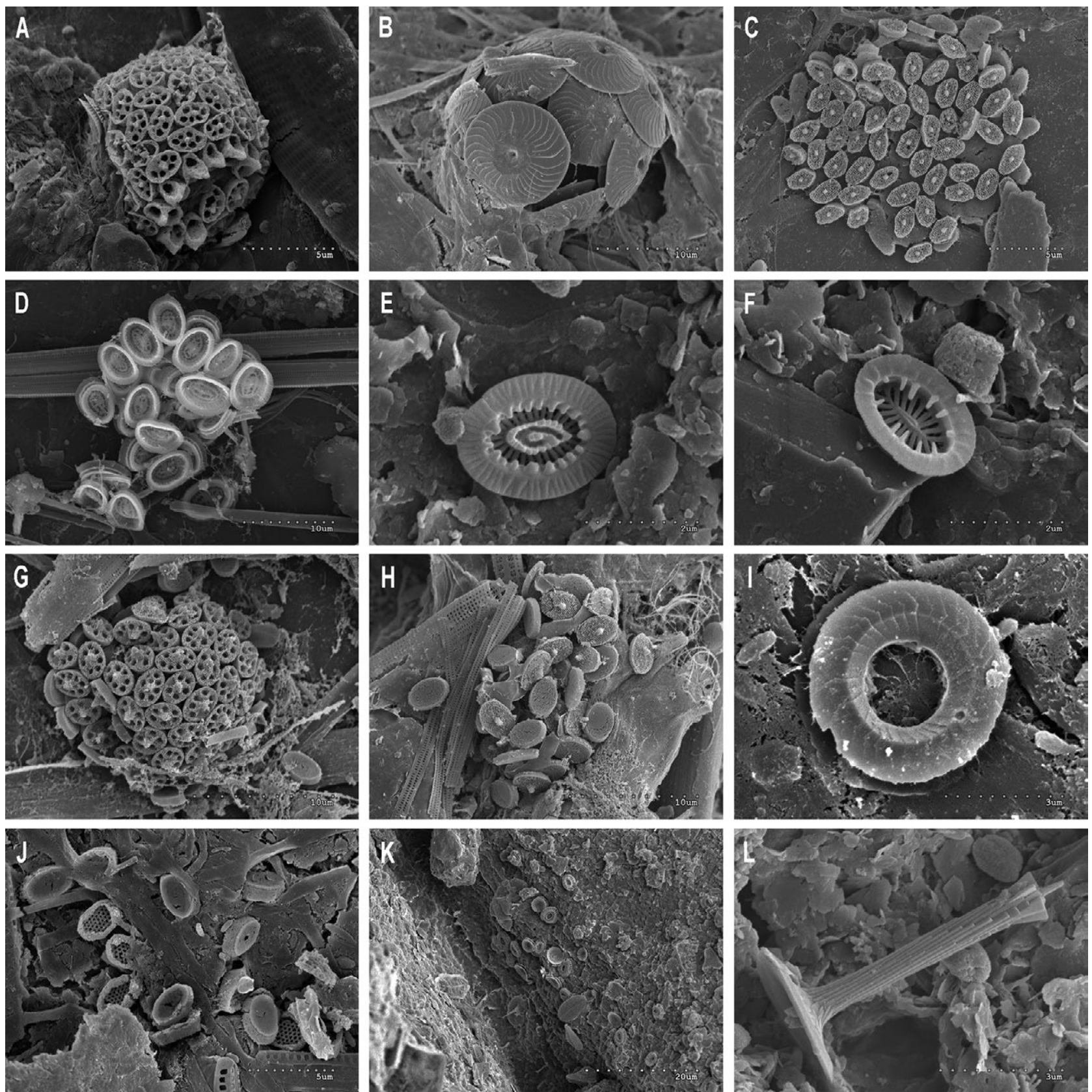

Fig. 4. - Coccolithophores. A, Coronosphaera mediterranea HOL (formerly "Calyptrolithina wettsteinii”'); B, Calcidiscus leptoporus; C, Zygosphaera hellenica; D, Syracosphaera pulchra; E, Syracosphaera molischii; F, Syracosphaera halldalii; G, Helicosphaera carteri HOL (for.

"Syracolithus confusus"); H, Helicosphaera carteri HOL (for. "Syracolithus catilliferus"); I, Umbilicosphaera sibogae; J, Holococcosphaera dentate (for. "Calyptrosphaera"); K, Coccoliths of Emiliania huxleyi on sediment; L, Rhabdosphaera clavigera.

identified only on one occasion (Fig. 2). Additionally, resting spores were detected in several pelagic samples (Fig. 5) and diatoms symbiotic of hydrozoans were identified on benthic plastics (Fig. 6F).

Thecate and athecate specimens of dinoflagellates were attached especially on pelagic samples (Table 1). Among the thecate dinoflagellates, Prorocentrum minimum (Fig. 3E), Prorocentrum micans, Ceratium sp., Pentapharsodinium tirrenicum (Fig. 3C), Dinophysis sp. (Fig. 3D), Coolia sp. (Fig. 3A, B) and Prorocentrum lima (Fig. 3F) had been described as epiphyte species. Coolia sp. appeared only on pelagic and benthic MPD collected in the Cap of Creus study area. Heterocapsa sp. (Fig. 3G, H) and other unidentified athecate dino- flagellates (Fig. 3I) also appeared in the samples but these organisms were less frequent.

Coccolithophores were identified on both pelagic and benthic MPD (Table 1) but coccospheres appeared only on pelagic MPD (Fig. 4A, B, C, D, G), while individual coccoliths were relatively abundant on benthic MPD. Emiliania huxleyi was the most abundant species on benthic and pelagic MPD, where it appeared in large quantities (Fig. 4K). Several species of Syracosphaera (S. pulchra, S. halldalii, S. molischii) (Fig. $4 \mathrm{D}, \mathrm{E}, \mathrm{F})$ were highly frequent on pelagic MPD. Additional species identified on pelagic plastics were Syracolithus confusus, Calcidiscus leptoporus, Coronosphaera mediterranea HOL (formerly, Calyptrolithina 

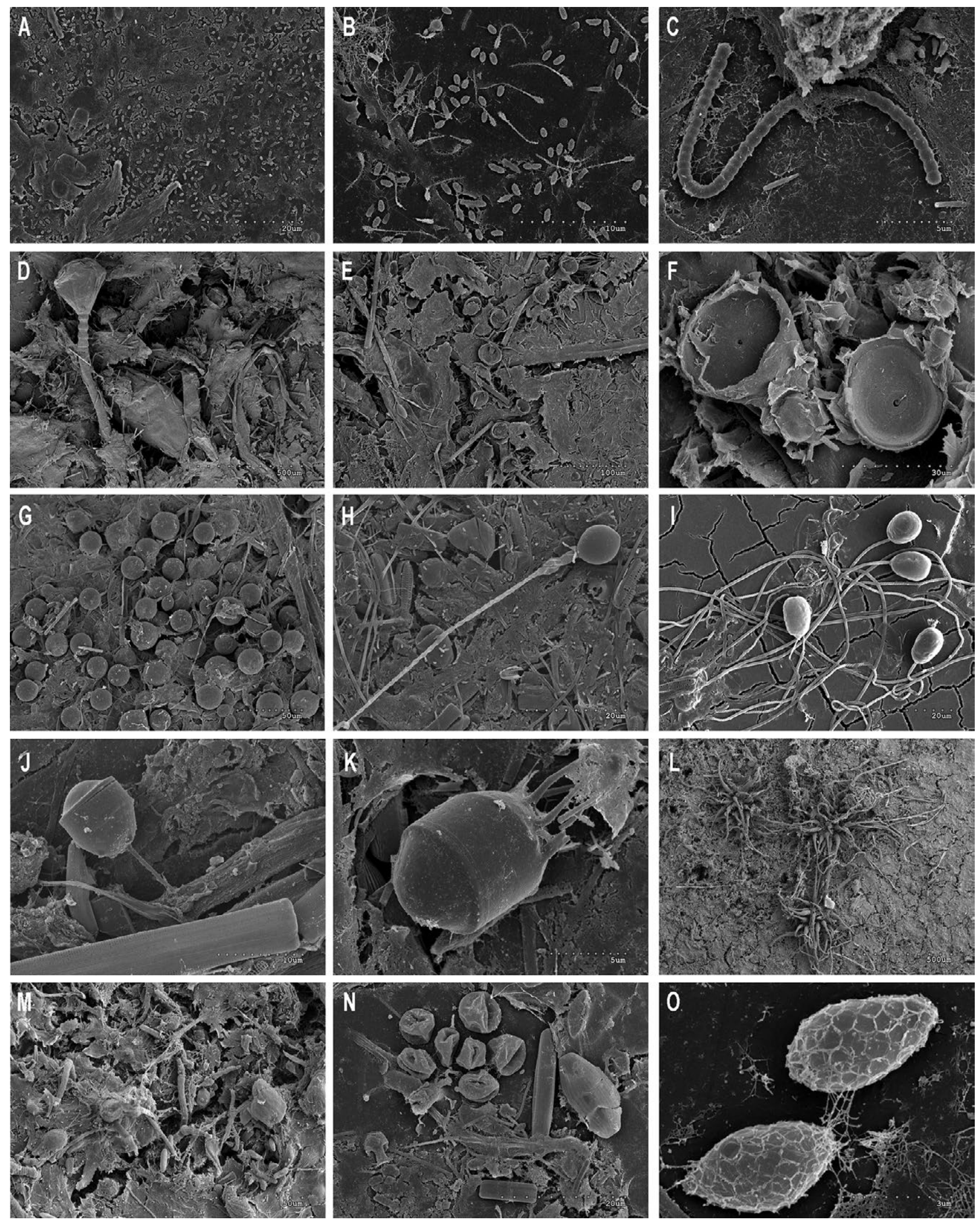

Fig. 5. - Organisms on pelagic plastics. A-B, bacteria on biofilms; C, cyanobacteria; D, E, F, different species of hydrozoans. G, H, I, nematocysts. J, K, resting spores; L, fungi; M, general image of biofilms with bacteria, fungi, diatoms and unidentified organisms; N, O, unidentified organisms.

wettsteinii), Zygosphaera hellenica, Calyptrosphaera dentata, coccoliths of Umbilicosphaera sibogae, and Scyphosphaera apsteinii. Rhabdosphaera clavigera, Helicosphaera carteri HOL (formerly Syracolithus catilliferus) were present on both habitats and Umbellosphaera sp. and Calcidiscus sp. were identified only on benthic MPD. Unidentified holococcoliths were also present. 

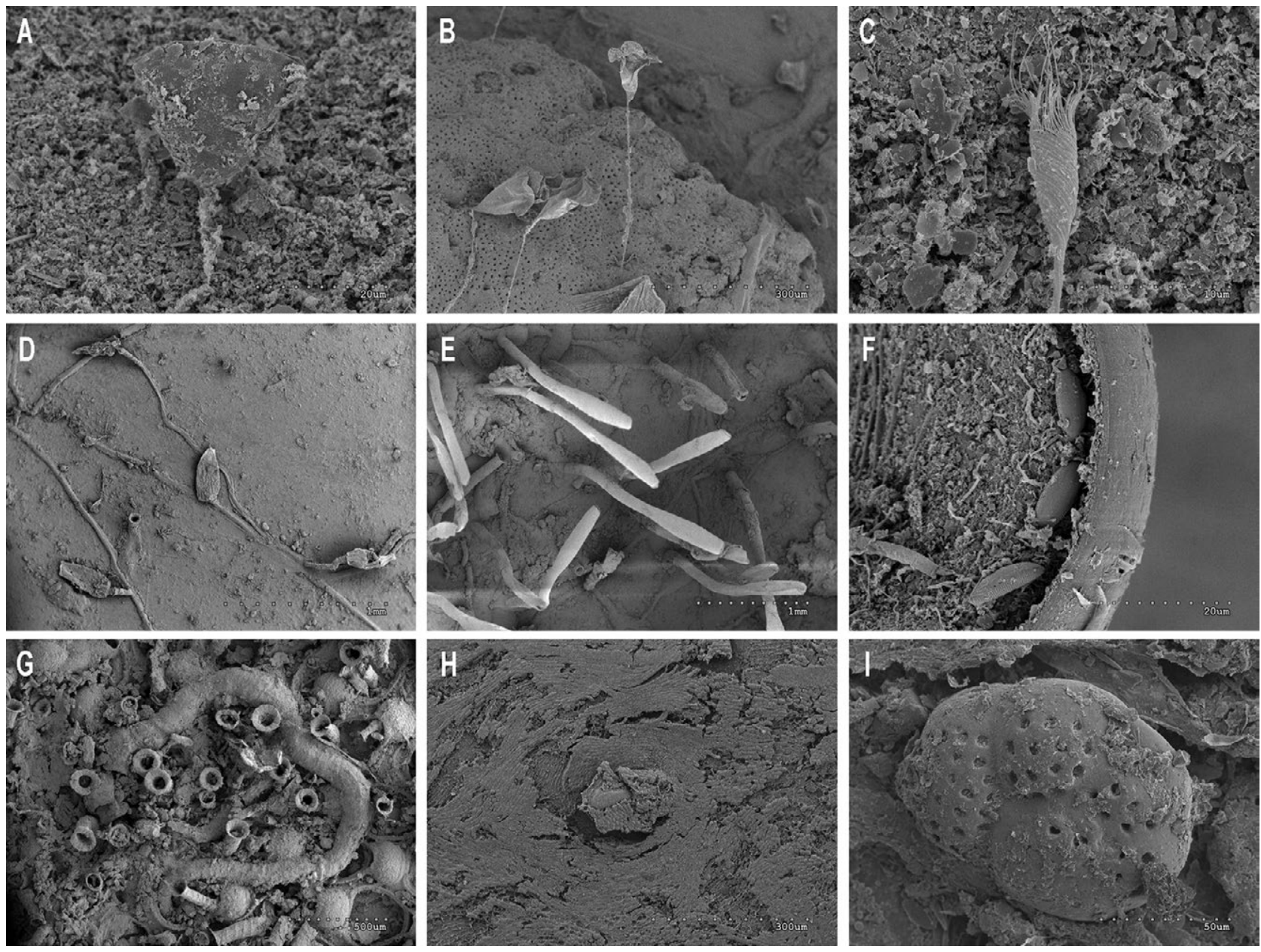

Fig. 6. - Organisms on benthic plastics. A, B, C, D, protozoans; E, hydrozoans; F, detail of benthic diatom living in hydrozoan; G, tube of polychaete; $\mathrm{H}$, bryozoan colony; I, foraminifera.

Other biological structures such as eggs and jellyfish nematocysts were identified attached to pelagic MPD (Fig. 5G, H, I). Pollen grains appeared in some samples in great numbers. Different remains or pieces of copepods or other crustaceans were common organic structures. However, the presence of unidentified organisms or structures was very common (Fig. 5N, O).

\section{DISCUSSION}

In the present study the SEM analysis of the microfouling community on macroplastics across three areas within Mediterranean coastal waters of Greece, Italy and Spain allowed the microfouling community on plastic substrate collected from pelagic and benthic habitats to be compared for the first time. Results indicated substantial differences between benthic and pelagic microfouling communities. We identified six zoological groups colonizing plastics from both habitats, with clear differences in incidence (Table 1). Diatoms were the most abundant biofilm component on MPD from both pelagic and benthic habitats. These organisms are known to maintain and increase the biofilm layer (Bravo et al. 2011, Zettler et al. 2013). Among the 14 genera of diatoms identified, some taxa had been previously described as components of the microfouling community on pelagic MPD (Table 2). Furthermore, most of them have also been described as benthic diatoms: i) members of the epiphytic communities of macrophytes or macroalgae (Majewska et al. 2014), ii) diatoms of the epilithic communities that grow attached to submerged stones (Totti et al. 2007), and iii) diatoms of epipelic communities which reside in the water/ sediment interface (Round et al. 1990).

Only six of the identified genera of diatoms were common on MPD from pelagic and benthic domains: Ceratoneis, Cocconeis, Navicula, Achnantes, Amphora and Fragilariopsis. Among them, only the genus Cocconeis showed a relatively high frequency (38\%) on benthic plastics. This epiphytic diatom has been described in the Mediterranean as the dominant genus in the epiphytic communities of Posidonia oceanica, The second and third species in abundance on benthic MPD (Amphora and Navicula) are also components of this epiphytic community (Majewska et al. 2014).

The majority of the dinoflagellates detected in our samples (58\% in pelagic and $13 \%$ in benthic MPD) are also described as epiphytic organisms. Coolia sp., Prorocentrum lima and Prorocentrum micans are rarely found in the water column. However, after turbulent, 
mixing events, these species can be found in surface waters of Mediterranean beaches (Vila et al. 2001).

Ceratoneis closterium was the most frequently identified diatom on floating MPD. This species is an epipelic diatom residing in the water/sediment interface and rarely found in the water column. This epipelic EPS producer species has been linked with the mucilage events that affect the Adriatic Sea with unusually high frequency (Najdek et al. 2005). Long gelatinous fronts, spreading up to tens of kilometres in length, extend over large areas in the northern Adriatic, causing great economic losses associated with fishing activities and tourism (Giani et al. 2005).

Among the dinoflagellates detected in our samples, a planktonic species, Prorocentrum minimum, is considered harmful due to its capacity to form high biomass blooms at beaches or in harbours with restricted water circulation in the Mediterranean (Vila and Masó 2005).

Our results add new evidence of the role of MPD as potential transport vectors for noxious events in the Mediterranean (Masó et al. 2003). In the Mediterranean, the majority of $\mathrm{HAB}$ events are produced by dinoflagellates, whose life-history strategies play a key role in combination with meteorological and marine physical features, such as fronts, convergences (Basterretxea et al. 2005, Masó and Garcés 2006) and sites with low water renewal such as harbours (Vila et al. 2001). The same physical processes that permit microalgae to develop high biomass blooms or mucilage events act on floating plastics, favouring their accumulation and giving microalgae the opportunity to attach to the abiotic substrate.

The nature of the synthetic polymer (Browne et al. 2010), its size, shape and its colonization by biofouling organisms (Morét-Ferguson et al. 2010, Lobelle and Cunliffe 2011) determine the buoyancy of the MPD and, consequently, its surface transport by wind and currents or its sinking to the seafloor. Along its journey through the marine environment, MPD provides a new substrate on which a succession of colonizing organisms can find a suitable habitat to persist, forming what Goldstein et al. (2014) called "islands" of substrate-associated organisms. The process of colonization causes density changes in MPD, which, in combination with the effect of currents, may cause their sinking to the seabed. Once on the seabed, the process of colonization continues (Fortuño et al. 2010, Demestre and Masó 2012, Sánchez et al. 2013). Not only macroplastics but also microplastics are subject to microfouling (Reisser et al., 2014). During the SPURS-MIDAS (March-April 2013) oceanographic cruise in the North Atlantic subtropical gyre (Font et al. 2014), neuston samples were collected in order to capture microplastics and see the degree of colonization by microorganisms. Well-developed microfouling communities were observed on most of the microplastic captured (Masó, pers. comm.).

Sánchez et al. (2013) described changes of the softbottom macro-organisms communities due to the accumulation of MPD. The colonization of plastic debris by primarily inhabitants of rocky or gravelly bottoms could have further consequences for the ecosystem function- ing, e.g. by modifying the habitat at a small spatial scale and facilitating the introduction of species, leading to new negative/positive species interactions. In the pelagic domain these potential changes are difficult to assess, but our results from SEM analyses of microfouling communities indicate that pelagic MPD was colonized by members of the epilithic, epiphytic and epipelic microalgae communities (Round 1990). In their original environment these microalgae deal with high levels of turbulence, and the secretion of EPS is an adaptive strategy in these habitats (Consalvey et al. 2004). Therefore, it is not surprising that plastic is a suitable habitat for them. MPD collected in the pelagic environment could have been colonized on the seabed in the near-coastal zone and refloated due to meteorological conditions or due to a gain in buoyancy caused by grazing. Floating plastics will be advected to the shoreline by daily breeze conditions or by local meteorological events. When breeze conditions reverse (wind flowing from earth to open sea), they would be washed offshore and dispersed, so the microfouling organisms can extend their distribution range and/or be the inoculum for the next bloom event. Although our results showed that there were some common species on pelagic and benthic MPD, we were unable to elucidate the source of the fouling communities. The process of sinking and refloating could be a key issue in the study of plastic fate, and therefore needs further investigation.

It is widely recognized that plastic pollution is a global problem and, though research on this topic has increased dramatically in recent decades (Derraik 2002, Cole et al. 2011, Cózar et at. 2015), we are still far from understanding its real consequences. Our results show that the microfouling communities attached to both benthic and floating MPD are dominated by benthic diatom genera. How this highly available substrate would modify their biogeography is an open issue. In fact, remarkably little is yet known about geographic distribution of diatoms (Vanormelingen et al. 2008), and in future studies MPD should be considered as a dispersion vector. Overall, our results highlight the need for further research in order to elucidate the role of MPD in increasingly harmful events at a global scale, either by extending the range of distribution of noxious species or by favouring some species rather than others.

\section{ACKNOWLEDGEMENTS}

The authors wish to thank L. Arín, L. Cros, M. Delgado, J.M. Gili and M. Vila for their help in the identification of organisms. We are indebted to Jordi Font for giving us the opportunity to increase our knowledge of MPD during the SPURS-MIDAS oceanographic cruise. We also thank the participants of the COMSOM oceanographic cruise (CTM2008-04206-E/MAR) and the crew of V/R García del Cid. The authors wish to thank two anonymous referees for their useful suggestions for improvement. This study was carried out in the framework of the COMSOM project (CTM20084617/MAR) funded by the Spanish Ministerio de Ciencia e Innovación. 


\section{REFERENCES}

Aliani S., Molcard A. 2003. Hitch-hiking on floating marine debris: macrobenthic species in the Western Mediterranean Sea. Hydrobiologia 503: 59-67.

http://dx.doi.org/10.1023/B:HYDR.0000008480.95045.26

Andrady A.L. 2011. Microplastics in the marine environment. Mar. Pollut. Bull. 62(8): 1596-1605. http://dx.doi.org/10.1016/j.marpolbul.2011.05.030

Barnes D.K.A. 2002. Biodiversity - Invasions by marine life on plastic debris. Nature 416: 808-809. http://dx.doi.org/10.1038/416808a

Barnes D.K.A., Galgani F., Thompson R.C., et al. 2009. Accumulation and fragmentation of plastic debris in global environments. Phil. Trans. R. Soc. B 364: 1985-1998. http://dx.doi.org/10.1098/rstb.2008.0205

Basterretxea G., Garcés E., Jordi A., et al. 2005. Breeze as Alexandrium taylori bloom favoring mechanism in a Mediterranean pocket beach. Est. Coast. Shelf Sci. 62: 1-12. http://dx.doi.org/10.1016/j.ecss.2004.07.008

Billingham N.C., Chiellini E., Corti A., et al. 2002. Environmentally degradable plastics based on oxo-biodegradation of conventional polyolefins. NCB, Pisa paper.

Bravo M., Astudillo J.C., Lancellotti D., et al. 2011. Rafting on abiotic substrata: properties of floating items and their influence on community succession. Mar. Ecol. Prog. Ser. 439: 1-17. http://dx.doi.org/10.3354/meps09344

Browne M.A., Galloway T.S., Thompson R.C. 2010. Spatial patterns of plastic debris along estuarine shorelines. Environ. Sci. Technol. 44(9): 3404-3409. http://dx.doi.org/10.1021/es903784e

Callow M.E., Callow J.A. 2002. Marine biofouling: a sticky problem. Biologist 49(1): 1-5.

Callow J.A., Callow M.E. 2011. Trends in the development of environmentally friendly fouling-resistant marine coatings. Nat. Commun. 2: 244. http://dx.doi.org/10.1038/ncomms 1251

Carpenter E.J., Smith K.L. 1972. Plastics on the Sargasso Sea surface. Science 175(4027): 1240-1241. http://dx.doi.org/10.1126/science.175.4027.1240

Carson H., Nerheim M., Carroll K., et al. 2013.The plastic-associated microorganisms of the North Pacific Gyre. Mar. Pollut. Bull. 75: $126-132$. http://dx.doi.org/10.1016/j.marpolbul.2013.07.054

Cole M., Lindeque P., Halsband C., et al. 2011. Microplastics as contaminants in the marine environment: a review. Mar. Pollut. Bull. 62(12): 2588-2597 http://dx.doi.org/10.1016/j.marpolbul.2011.09.025

Cole M., Lindeque P., Fileman E., et al. 2013. Microplactic ingestion by zooplankton. Environ. Sci. Technol. 47: 6646-6655.

Consalvey M., Paterson D.M., Underwood G.J.C. 2004. The ups and down of life in a benthic biofilm: migration of benthic diatoms. Diatom Res. 19(2): 181-202. http://dx.doi.org/10.1080/0269249X.2004.9705870

Cózar A., Sanz-Martín M., Martí E., et al. 2015. Plastic accumulation in the Mediterranean Sea. PLoS ONE 10(4): e0121762. http://dx.doi.org/10.1371/journal.pone.0121762

Cros L., Fortuño J.M. 2002. Atlas of Northwestern Mediterranean coccolithophores. Sci. Mar. 66(Suppl.1): 7-182.

de Juan S., Demestre M. 2012. A trawl disturbance indicator to quantify large scale fishing impact on benthic ecosystems. Ecol. Indic. 18: 183-190 http://dx.doi.org/10.1016/j.ecolind.2011.11.020

de Juan S., Demestre M., Sanchez P. 2011. Exploring the degree of trawling disturbance by the analysis of benthic communities ranging from a heavily exploited fishing ground to an undisturbed area. Sci. Mar. 75: 507-516. http://dx.doi.org/10.3989/scimar.2011.75n3507

Delgado M., Fortuño J.M. 1991. Atlas de fitoplancton del Mar Mediterráneo. Sci. Mar. 55(Suppl. 1): 1-133.

Demestre M., Masó M. 2012. Plàstics al fons marí: el projecte COMSOM a Palamós. Càtedra d'Estudis Marítims (Universitat de Girona) i Museu de la Pesca (eds). Pesca i Ciència: Quaderns Blaus. QB, 028: 58 pp.

Demestre M., Martin J., Mytilineou C., et al. 2010. Evaluation of the level of trawling perturbation on soft bottoms using acoustic remote sensing as a promising approach for fishing effort estimation. Rapp. Comm. int. Mer Médit. 39: 489.

Derraik J.G.B. 2002. The pollution of the marine environment by plastic debris: a review. Mar. Pollut. Bull. 44: 842-852.
http://dx.doi.org/10.1016/S0025-326X(02)00220-5

Eriksen M., Lebreton L.C.M., Carson H.S., et al. 2014. Plastic pollution in the World's Oceans: more than 5 trillion plastic pieces weighing over 250,000 tons afloat at sea. PLoS ONE 9(12): e111913.

http://dx.doi.org/10.1371/journal.pone.0111913

Flemming H.-C. 2009. Why microorganisms live in biofilms and the problem of biofouling. In: Flemming H.-C., Murthy P.S., Venkatesan R., et al. (eds), Marine and industrial biofouling. Springer Series on Biofilm, pp. 3-12. http://dx.doi.org/10.1007/978-3-540-69796-1_1

Flemming H.C., Neu T.R., Wozniak D.J. 2007. The EPS matrix: the "house of biofilm cells". J. Bacteriol. 189 (22): 7945-7947. http://dx.doi.org/10.1128/JB.00858-07

Font J., Ward B., SPURS-MIDAS Team., et al. 2014. Measuring surface salinity in the N. Atlantic subtropical gyre. The SPURS-MIDAS cruise, spring 2013. Geophys. Res. Abs. 16, EGU2014-10558.

Fortuño J.M., Masó M., Sáez R., et al. 2010. SEM microphotographs of biofouling organisms on floating and benthic plastic debris. Rapp. Comm. int. Mer Médit. 39: 358.

Galgani F., Leaute J.P., Moguedet P., et al. 2000. Litter on the sea floor along European Coasts. Mar. Pollut. Bull. 40(6): 516-527. http://dx.doi.org/10.1016/S0025-326X(99)00234-9

Giani M., Rinaldi A., Degobbis D. 2005. Mucilages in the Adriatic and Tyrrhenian Sea: An introduction. Sci. Total Environ. 353: 3-9. http://dx.doi.org/10.1016/j.scitotenv.2005.09.006

Goldstein M., Carson H., Eriksen M. 2014. Relationship of diversity and habitat area in North Pacific plastic-associated rafting communities. Mar. Biol. 161: 1441-1453. http://dx.doi.org/10.1007/s00227-014-2432-8

Gregory M.R. 2009. Environmental implications of plastic debris in marine settings-entanglement, ingestion, smothering, hangerson, hitch-hiking and alien invasions. Phil. Trans. R. Soc. B 364 : 2013-2025.

http://dx.doi.org/10.1098/rstb.2008.0265

Hammer J., Kraak H.S.M., Parsons J.R. 2012. Plastics in the marine environment: the dark side of a modern gift. Rev. Environ. Contam. T. 220: 1-44 http://dx.doi.org/10.1007/978-1-4614-3414-6_1

Harshvardhan K., Jha B. 2013. Biodegradation of low-density polyethylene by marine bacteria from pelagic waters, Arabian Sea, India. Mar. Pollut. Bull. 77: 100-106. http://dx.doi.org/10.1016/j.marpolbul.2013.10.025

Katsanevakis S., Verriopoulos G., Nicolaidou A., et al. 2007. Effect of marine litter on the benthic megafauna of coastal soft bottoms: a manipulative field experiment. Mar. Pollut. Bull. 54: 771-778. http://dx.doi.org/10.1016/j.marpolbul.2006.12.016

Lobelle D., Cunliffe M. 2011. Early microbial biofilm formation on marine plastic debris. Mar. Pollut. Bull. 62: 197-200. http://dx.doi.org/10.1016/j.marpolbul.2010.10.013

Majewska R., D’Alelio D., De Stefano M. 2014. Cocconeis Ehrenberg (Bacillariophyta), a genus dominating diatom communities associated with Posidonia oceanica Delile (monocotyledons) in the Mediterranean Sea. Aquat. Bot. 112: 48-56. http://dx.doi.org/10.1016/j.aquabot.2013.07.008

Mato Y., Isobe T., Takada H., et al. 2001. Plastic resin pellets as a transport medium for toxic chemicals in the marine environment. Environ. Sci. Technol. 35: 318-324. http://dx.doi.org/10.1021/es0010498

Masó M., Garcés E. 2006. Harmful microalgae blooms (HAB); problematic and conditions that induce them. Mar. Pollut. Bull. 53: $620-630$. http://dx.doi.org/10.1016/j.marpolbul.2006.08.006

Masó M., Garcés E., Pagés F., et al. 2003. Drifting plastic debris as a potential vector for dispersing harmful algal bloom (HAB) species. Sci. Mar. 67: 107-111.

Morét-Ferguson S., Law K.L., Proskurowski G., et al. 2010. The size, mass, and composition of plastic debris in the western North Atlantic Ocean. Mar. Pollut. Bull. 60: 1873-1878. http://dx.doi.org/10.1016/j.marpolbul.2010.07.020

Najdek M., Blazina M., Djakovac T., et al. 2005. The role of the diatom Cylindrotheca closterium in a mucilage event in the northern Adriatic Sea: coupling with high salinity water intrusions. J. Plankton Res. 27 (9): 851-862. http://dx.doi.org/10.1093/plankt/fbi057

O’Brine T., Thompson R.C. 2010. Degradation of plastic carrier bags in the marine environment. Mar. Pollut. Bull. 60: 
2279-2283.

http://dx.doi.org/10.1016/j.marpolbul.2010.08.005

Reisser J., Shaw J., Hallegraeff G., et al. 2014. Millimeter-sized marine plastics: a new pelagic habitat for microorganisms and invertebrates. PLoS ONE 9(6): e100289.

http://dx.doi.org/10.1371/journal.pone.0100289

Round F.E., Crawford R.M., Mann D.G. 1990. The diatoms. Biology and morphology of the genera. Cambridge Univ. Press, Cambridge, $747 \mathrm{pp}$.

Sánchez P., Masó M., Sáez R., et al. 2013. Baseline study of the distribution of marine debris on soft-bottom habitats associated with trawling grounds in the northern Mediterranean. Sci. Mar. 77(2): 247-255 http://dx.doi.org/10.3989/scimar03702.10A

Schultz M.P. 2007. Effect of coating roughness and biofouling on ship resistance and powering. Biofouling 23(5): 331-341. http://dx.doi.org/10.1080/08927010701461974

Totti C., Cucchiari E., De Stefano M., et al. 2007. Seasonal variations of epilithic diatoms on different hard substrates, in the northern Adriatic Sea. J. Mar. Biol. Ass. U.K. 87: 649-658. http://dx.doi.org/10.1017/S0025315407054665

Thiel M., Gutow L. 2005. The ecology of rafting in the marine environment. II. The rafting organisms and community. Oceanogr. Mar. Biol. Annu. Rev. 43: 279-418. http://dx.doi.org/10.1201/9781420037449.ch7

Thiel M., Hinojosa I., Vásquez N., et al. 2003. Floating marine debris in coastal waters of the SE-Pacific (Chile). Mar. Pollut. Bull. 46: 224-231. http://dx.doi.org/10.1016/S0025-326X(02)00365-X

Vanormelingen P., Verleyen E., Vyverman W. 2008. The diversity and distribution of diatoms: from cosmopolitanism to narrow endemism. Biodivers. Conserv. 17: 393-405. http://dx.doi.org/10.1007/s10531-007-9257-4

Vila M., Masó M. 2005. Phytoplankton functional groups and harmful algal species in anthropogenically impacted waters of the NW Mediterranean Sea. Sci. Mar. 69: 31-45.

Vila M., Garcés E., Masó M. 2001. Potentially toxic epiphytic dinoflagellate assemblages on macroalgae in the NW Mediterranean. Aquat. Microb. Ecol. 26: 51-60. http://dx.doi.org/10.3354/ame026051

Webb H.K., Crawford R.J., Sawabe T., et al. 2009. Poly(ethylene terephthalate) polymer surfaces as a substrate for bacterial attachment and biofilm formation. Microbes Environ. 24(1): $39-42$. http://dx.doi.org/10.1264/jsme2.ME08538

Zettler E.R., Mincer T.J., Amaral-Zettler L.A. 2013. Life in the "Platisphere": microbial communities on plastic marine debris. Environ. Sci. Technol. 47: 7137-7146. 